\title{
Da imagem do real para o real da imagem: por um elogio das aparências
}

\author{
MARCOS BECCARI \\ DANIEL B. PORTUGAL
}

Resumo

Este artigo se debruça sobre teorias que criticam a - já abalada, mas ainda comum - concepção das aparências como algo traiçoeiro e que deveria ser sempre julgado em função de qualquer coisa para além dele. Recorremos a pensadores como Nietzsche, Bergson, Rosset, Lacan e Žižek, dentre outros, para mostrar que a relação entre o real e as imagens pode ser vista não apenas como necessária, mas - apesar dos paradoxos que a permeiam - também como passível de afirmar a vida, mais do que as concepções que tentam buscar um real inexistente para além dessa relação. Para ilustrar nossos argumentos, recorremos a filmes como Um corpo que cai e Sinédoque, Nova Iorque, dentre outros.

Palavras-chave:

Imagem, real, aparência 


\title{
From the image of the real to the real of the image: an eulogy of appearances
}

\author{
MARCOS BECCARI \\ DANIEL B. PORTUGAL
}

\begin{abstract}
This articles studies different critiques to the conception of appearances as something treacherous and that should always be judged in reference to something transcendental. Based on such authors as Nietzsche, Bergson, Rosset, Lacan and Žižek, among others, we show that the relation between images and the real is a necessary one. The point of view that recognizes this complementarity between image and the real is more likely to affirm life - in Nietzschian terms - than conceptions that seek a metaphysical Real beyond this relation. To illustrate our argument, we make reference to movies such as Vertigo and Synecdoche, New York, among others.
\end{abstract}




\section{Imagens, máscaras ou aparências}

Há muitas formas de olhar para o "mundo", isto é, para aquilo que aparece para nós em nossa experiência ordinária. Talvez a mais recorrente, ou próxima do senso comum, seja encarando as coisas desse mundo como se aquilo que experimentamos através dos sentidos (a imagem) existisse independentemente de nós. Esta é uma maneira realista de lidar com o mundo seja um realismo ingênuo que simplesmente toma a imagem como o real, seja um realismo mais elaborado que considera uma realidade ou "coisa em si" existente "por baixo" das imagens. Mas alguém poderia dizer que o mundo em si mesmo não existe, porque não há como provar sua existência sem um critério ou um observador externo a ele. Esse é um caminho idealista de lidar com o mundo, na medida em que o mesmo precisaria de um suporte ideal, metafísico ou transcendente para justificar-se como "mundo". Outra forma de entender nossa relação com o mundo é dizer que ele existe, e nada existe além dele, só que nunca conseguimos percebê-lo exatamente como ele é. Haveria então algum tipo de mediação (como uma imagem, uma "aparência", um filtro) que nos impede de enxergar este mundo em si mesmo e que, ao mesmo tempo, seria o que nos dá acesso a ele.

Trata-se de uma visada que reconhece que cada possível forma de olhar nunca se resguarda de uma complexa rede de práticas sociais e discursos circulantes em determinada configuração histórica. E, assim como nenhuma configuração histórica isola-se das demais, também as "formas de olhar" misturam-se e sobrepõem-se umas às outras nos modos de se perceber, conhecer e habitar o mundo. Poderíamos tentar retomar, por exemplo, a experiência perceptiva do final do século XIX mediada por tecnologias como a fotografia, a 
telegrafia, viagens de trem etc. De acordo com o historiador Jonathan Crary (1992), tal experiência diz respeito a uma reconfiguração radical do modelo epistemológico vigente nos séculos XVII e XVIII. Se antes as imagens percebidas eram consideradas efeito de leis naturais, de base newtoniana, que independiam de um corpo humano até então entendido como "enganador", uma nova experiência teria sido convocada, sobretudo a partir de Goethe (em sua conhecida doutrina das cores), no início do século XIX: a de que as imagens também são efeito de um olho que vê e ao mesmo tempo as produz.

Este percurso de modernização da percepção, explorado por Crary, corresponderia a um segundo movimento da "modernidade": da transparência de um olho que capta um mundo externo prévio passa-se a uma visão ancorada na corporeidade do observador, de modo que o próprio objeto de conhecimento e da percepção (o mundo) perde seu caráter assegurado de algo previamente dado. Se é verdade que hoje estaríamos inseridos em uma nascente cultura do espetáculo - recorrentemente associada a formas variadas de "desatenção", fragmentação, desreferencialização etc. -, parece extremamente importante refletirmos sobre a desestabilização das certezas concernentes tanto ao real quanto ao ilusório e à possível liberação da imagens das supostas referências externas que lhe emprestavam valor.

Com isso em mente, voltemos às considerações sobre o estatuto ontológico das "aparências" ou das imagens. Consideramos, acima, a imagem como mediadora entre um sujeito e algo para além dele. Mas, ao considerá-la assim, não continuaríamos opondo a aparência ao real? Para o filósofo nietzschiano Clément Rosset (2006), a resposta é não. Essa aparência mediadora, afinal, é a única coisa efetivamente real, de modo que o eu-observador e a coisa-observada fazem parte de uma mesma aparência. Tal proposição será aqui imprescindível não só por rejeitar a oposição clássica entre aparência e realidade, mas principalmente por uni-las em oposição à ilusão de um "mundo verdadeiro", tal como proclamava Nietzsche (2006, p. 26 [III, §2], destaques no original) no fim do século XIX: "O mundo 'aparente' é o único. O 'mundo verdadeiro' é apenas acrescentado mendazmente”. O elogio de Nietzsche à aparência, portanto, coincide com o elogio ao real, pois o espaço da representação é precisamente o lugar onde se encontra o real. Não se trata de despojar a realidade de sua concretude, mas, antes, de abandonar a metafísica tradicional que opõe o mundo verdadeiro à realidade da aparência, isto 
é, à experiência imediata e sensível. De tal modo que a própria noção de mundo aparente também deixa de fazer sentido sem sua contraparte ilusória, o mundo verdadeiro. "Abolimos o mundo verdadeiro: o que restou? O aparente, talvez?... Não! Com o mundo verdadeiro abolimos também o mundo aparente!" (NIETZSCHE, 2006, p. 32 [IV, §6], destaques no original).

Imaginemos, para exemplificar a mudança de perspectiva proposta por Rosset (2006) a partir de Nietzsche, que alguém acabou de fazer um desenho e, por acidente, derrubou um vidro de nanquim nesse desenho. Quanto mais ele tentar limpar o nanquim, mais ele apagará o desenho que havia ali, de modo que, no final, sobra apenas um borrão. Tal situação seria análoga ao fato de que, se tentarmos "limpar" as aparências das coisas, não sobra nada, tudo é perdido definitivamente. Como escreveu Fernando Pessoa (1981, p. 140), na identidade de Alberto Caeiro, "O único sentido íntimo das cousas é elas não terem sentido íntimo nenhum".

Se não nos habituarmos ao "borrão do mundo", é porque ainda estamos esperando por algum sentido íntimo para além da aparência. Mesmo que não seja uma essência platônica, ao menos a tranquilidade de uma universalidade calcada na razão pura. Na concepção nietzschiana, porém, a realidade não é tributária do crédito que se concede ou que se deixa de conceder à autoridade de um nível metafísico, esse "para além" do mundo empiricamente vivido.

Continuando a reflexão gerada pelo exemplo anterior, vale a pena deixar explícito que não se trata de dizer que a realidade é necessariamente um borrão, e sim que ela pode facilmente começar a parecer-se com um quando tentamos "retocá-la" - o que dá no mesmo que tentar enxergar, para além dela, algum divino pintor que a fundamente. $O$ jargão de que "as aparências enganam" resume o diagnóstico perene do sentimento de insuficiência e de falta acerca da realidade em geral e de toda experiência em particular. Ou seja, se, muitas vezes, o que vemos é um borrão, falta de sentido ou de ordem, isso não se deve à imperfeição da ordem do mundo sensível frente a ordens cósmicas ou divinas, e sim, unicamente, ao fato de que esperávamos outro sentido ou outra ordem que não aquela que nos foi dada. É isso que mostra Bergson (2006) em $A$ evolução criadora, quando questiona a positividade da noção de desordem. Ora, não é possível haver uma "falta de ordem" positiva do mesmo modo que, quando pegamos um livro em versos, não vemos "falta de prosa", e sim versos. Apenas se encararmos os versos de maneira negativa, por aquilo 
que eles não são, mas poderiam ser é que chegamos à "desprosa" - falta de prosa. A costumeira confusão relativa à ordem e à desordem está diretamente ligada à dificuldade de se abandonar as noções de "essência" e "aparência", pois o mundo da essência não seria outro que o da completude da ordem. Bergson (2006, p. 242) argumenta que "a realidade é ordenada na exata medida em que satisfaz nosso pensamento. A ordem, portanto, é um certo acordo entre o sujeito e o objeto".

Dizer que a noção de desordem é necessariamente negativa, entretanto, não é o mesmo que "refutá-la". A desordem evidentemente existe para nós, porque não é possível viver sem expectativas, ainda que muitas vezes frustradas. Com efeito, para Bergson (2001), é a própria possibilidade virtual de nossas ações que faz o mundo ser incompleto, aberto, prenhe de possibilidade - o mundo que aparece para nós já é o mundo na medida em que ele é passível de ser objeto de nossas ações. A aparência não consiste apenas na "superfície" do que vemos, mas principalmente em tudo o que nela não vemos, de modo que sua profundidade reside em tudo o que ela teria ainda a nos revelar, inesgotável em sua "insuficiência" aparente.

Nietzsche oferece, neste aspecto, diagnóstico muito semelhante. É possível observar que, em seu pensamento, a ideia de "máscara", por exemplo, nunca aparece como disfarce, indício de falsidade ou situação de logro. Pelo contrário, ela se apresenta como mais seguro indício do real, já que seu caráter fundamental é de ser expressão e não dissimulação do real, de ser a aparência como potência positiva, como imagem, e não como negatividade de um suposto real que estaria por trás dela.

\section{Da imagem do real}

Žižek define a arte como, entre outras coisas, aquilo que resiste à compreensão do conhecimento. A noção da arte como algo capaz de lidar com um nível de realidade não acessível à razão, como sabemos, está longe de ser nova. Dentre os filósofos que já a defenderam está Schopenhauer, para quem o artista digno desse nome cria uma representação da própria Idea platônica, enquanto o conhecimento abstrato lida apenas com fenômenos. Nas primeiras páginas de sua Metafísica do Belo, Schopenhauer (2003, p. 26) já adianta que "o conhecimento que não pode ser comunicado mediante doutrinas e conceitos, mas apenas por obras de arte, e não pode ser concebido in abstracto, mas apenas intuitivamente, é o conhecimento mais profundo e verdadeiro da essência propriamente dita do mundo". 
Na perspectiva de Žižek, entretanto, não se trata de utilizar a arte ou a beleza como veículo para apreender a essência do mundo, muito embora a beleza possa nos aproximar do "Real em nós mesmos", o núcleo não simbolizável de nossa subjetividade que, na teoria lacaniana - é nela que se baseia Žižek - é denominado Coisa (das Ding). "O Belo artístico é a máscara que o abismo da Coisa Real, a Coisa resistindo à simbolização, veste quando aparece" (ŽIŽEK, 2008, p. 211). Lacan propõe seu conceito de Coisa, que ele toma emprestado do Projeto (Entwurf) freudiano, em seu Seminário VII. Neste seminário, o psicanalista subverte completamente as relações comumente levantadas entre o Desejo e o Bem. O desejo é visto, aqui, como fluxo engendrado pelas descargas pulsionais, e não pelos seus pretensos objetos, isto é, pelas imagens às quais ele se associa (um corpo, uma viagem, um título etc.). $\mathrm{O}$ desejo humano é, em última instância, desejo de nada, desejo de morte. É para designar esse objeto paradoxal ao redor do qual nossa subjetividade gira e que só esconde o nada da morte que Lacan utiliza o conceito de Coisa. Ora, o desejo, embora engendrado pela Coisa, só pode se manter vivo na medida em que se mantém afastado dela. O Bem, portanto, é aquilo que se opõe à lógica do desejo, ao mesmo tempo em que garante, por outro lado, a sobrevivência desse mesmo desejo. É por isso que Lacan (2008, p. 274) afirma que "o que se chama defender seus bens é apenas uma única e mesma coisa que proibir a si mesmo de gozar deles". A noção de que estamos "condenados" à incompletude pela própria estrutura de nossos desejos pode, sem dúvida, ser caracterizada como trágica. Podemos pensar que ela nos faz perceber o "absurdo da existência" de que fala Nietzsche (2007) em O nascimento da tragédia.

A fantasia, a criação estética e a beleza, entretanto, revelamnos a possibilidade de uma vida que é afirmada pelo próprio absurdo e por sua expressão fantasiosa, como no caso dos deuses do Olimpo que "legitimam a vida humana pelo fato de eles próprios a viverem [...]" (NIETZSCHE, 2007, p. 34 [\$3]). Como, pergunta Nietzsche (ibidem, p. 34 [\$3]), poderiam os gregos ou qualquer outro humano que não queira negar a realidade recorrendo aos supostos "Bens" - suportar a existência, "se esta, banhada de uma glória mais alta, não lhe fosse mostrada em suas divindades?". A beleza pode aparecer, assim, como aquilo que possibilita nos relacionarmos com nossos desejos sem negá-los. Isso porque, embora ela nos mantenha a certa distância da Coisa, ela não aparece como uma barreira. Lacan conclui, assim, que o belo, contrariamente ao bem, não nos engoda. 
Isto é, o belo afirma a realidade absurda do nosso desejo como tal, mas permanece "insensível ao ultraje" (LACAN, 2008, p. 284) que tal realidade poderia causar se vista pela perspectiva do Bem. Assim, a função do belo "nos abre os olhos e talvez nos acomode quanto ao desejo, dado que ele mesmo está ligado a uma estrutura de engodo" (ibidem, p.284).

Esta visão do belo, é importante notar, está em conexão direta com o entendimento do imaginário (no sentido rossetiano) como combustível da realidade e não seu substituto. A beleza, afinal, não eleva um ideal sobre o mundo, mas liga mundo e desejo na medida em que afirma o mundo ao duplicá-lo ou reiterá-lo. A análise que Žižek (2008) propõe do filme Um corpo que cai (1958), de Hitchcock, talvez nos ajude a compreender melhor este ponto. O que interessa, em tal filme, é o fato de que, nele, o que choca "não é o fato de descobrirmos que o original é uma mera cópia - uma ilusão comum contra a qual o platonismo nos adverte o tempo todo -, mas o fato de (o que havíamos acreditado ser) a cópia revelar-se como o original" (ŽIŽEK, 2008, p. 221). Interessa-nos compreender, a partir dessa reflexão, que a imagem não se resume a uma dicotomia entre cópia e original, ou entre realidade e fantasia, mas ao modo como uma aparência reordena a realidade em relação à fantasia: se aquilo que aparece será vivido e aprovado como real ou se será rechaçado em prol de uma suposição qualquer.

À análise zizekiana convém acrescentarmos que Hitchcock ocupa um lugar chave na teoria de Deleuze (2009) sobre o cinema, precisamente o lugar intermediário na transição da imagem-movimento para a imagem-tempo. Em contraposição ao cinema moderno, onde o espectador é levado à ação, participando como um dos agentes narrativos, o cinema de Hitchcock aponta para a transformação dos agentes em espectadores de seus próprios atos. Em Um corpo que cai, o incômodo que toma conta do protagonista Scottie - ao descobrir finalmente que Judy, a mulher que ele tentou transformar em Madeleine, é justamente (a mulher que ele conheceu como) Madeleine - coincide com o incômodo do olhar platônico ao perceber que o "original" procurado já é, em si mesmo, uma cópia. A inversão antiplatônica realizada por Hitchcock, pois, se traduz na seguinte questão: e se a "verdadeira" Madeleine já era Judy fazendo-se passar por Madeleine? Por conseguinte, a imagem-tempo instaurada pelo choque de Scottie no momento do reconhecimento (ao retornar com Judy ao local do suicídio de Madeleine) é representada de modo kafkiano: da mesma forma que, ao fim da parábola sobre a "Porta da Lei" 
em O Processo, o homem do campo aprende que a porta está lá apenas para ele - a porta em relação à qual ele se viu como testemunha acidental, permitindo-lhe um breve e proibido vislumbre, foi encenada e montada só para fasciná-lo -, em Um corpo que cai Scottie também tem de aceitar que o fascinante espetáculo de Madeleine, que ele investigava secretamente, fora encenado apenas para seu olhar e, portanto, que seu olhar estava incluído nele desde o princípio: sua fobia de altura garantiria o êxito da farsa.

Deste modo, o foco de Um corpo que cai reside na criação de uma aparência tão perfeita que, mesmo quando revelada enquanto aparência, não pode ser descartada: após descobrirmos a "verdadeira história" de Madeleine, a primeira parte do filme (até o falso suicídio) não é simplesmente descartada como sendo uma farsa - é como se houvesse mais verdade nessa aparência falsa do que na história verdadeira por trás da mesma. Tal como em um "crime perfeito" - cuja função é omitir o fato de que, em última análise, não há nada a ser roubado, de modo que a ilusão de que a vítima possuía o que foi roubado seja mantida -, a dificuldade não é identificar o elemento real que teria sido substituído na fantasia, mas sim qual é afinal o substituto ilusório dentro daquilo que insiste em nos parecer real. Ou seja, a dificuldade é assumir que, em última análise, não havia nada escondido por trás daquilo que se mostrava mera "aparência". O que ocorre no filme, pois, é que o olhar do espectador não é simplesmente paralisado pela ruptura da aparência, com a revelação de um real vertiginoso. É, antes, a aparência enquanto tal (que percebemos através de um ponto de revelação traumático-elusivo no espaço da "realidade" da história) que é a própria brecha por meio da qual o olhar se inscreve na realidade, o ponto no qual o sujeito encontra a si mesmo como "aquele que olha" - sendo este olhar não somente o próprio resíduo único (e necessário) da aparência que oculta todo o vazio de uma história "verdadeira", mas também a primordial fonte de vertigem (a profundidade abismal que ameaça engolir Scottie).

De modo análogo, há uma cena no filme Cidade dos Sonhos (2001), de David Lynch, na qual as protagonistas vão a um lugar chamado Clube Silencio - que por fora se assemelha a uma boate e por dentro é um teatro antigo. $\mathrm{O}$ homem que está no palco nos previne logo de início de que estaremos ouvindo uma música gravada de antemão, de que "não há banda e, não obstante, ouvimos a banda, é uma ilusão!". Enquanto soa um trompete, entra um homem tocando o instrumento; o músico abre 
os braços, afastando o trompete de sua boa, e o som permanece. Ocorre que, mesmo assim, as protagonistas Betty e Rita se emocionam e choram com o falso espetáculo. Com uma maquiagem carregada e um adorno em formato de lágrima colado na face, uma mulher entra em palco cantando uma música de imensa tristeza, proporcional à entrega da cantora que, de súbito, desmaia - mas seu canto permanece. Ao contrário da recorrente desmistificação que mágicos famosos operam na TV, realizando um número de mágica para em seguida mostrar o funcionamento do aparato que torna a ilusão possível, no Clube Silencio a lógica de desmistificação é invertida: primeiro é revelado o truque e depois prevalece a resistência da ilusão/aparência sobre a realidade ordinária. Sobretudo, apesar de ser parte da realidade, o espetáculo continua sendo percebido de modo ficcional, pois "Muito mais difícil que denunciar/desmascarar (o que aparece como) a realidade enquanto ficção é reconhecer na realidade 'real' a parte de ficção" (ŽIŽEK, 2008, p. 237).

Quando a cantora e sua lágrima falsa choram "por nós" antes mesmo que derrubemos qualquer lágrima, o canto se descola de seu suporte e a mentira do playback adquire mais "verdade" que o corpo da cantora, que colapsa junto à ilusão que a sustenta. Não como uma névoa que se dissipa em favor da sóbria realidade, e sim como uma aparência de "real" que persiste mesmo quando a (ficção da) realidade ordinária se desintegra, ou seja, como um encantamento que resiste à desmistificação. O insistente esclarecimento por parte do mestre de cerimônias, em três idiomas e com direito a demonstração (do trompetista), é totalmente impotente. Pois a efetividade das aparências é alheia à sua captura, funciona como uma mágica "sem truques", está nas vitrines e nas novelas tanto quanto em nossas relações mais "verdadeiras" uns com os outros. A um só tempo, a revelação e a permanência do nível aparente reforçam o ritual do qual participamos independentemente de quão "falso" ele seja, independentemente das racionalizações que criamos para justificar nossa participação. Tanto Um corpo que cai quanto Cidade dos Sonhos, portanto, nos ajudam a averiguar esta complexa e fugidia concepção de "real" que não necessariamente se opõe à imaginação ou à aparência. Trata-se, propõe Rosset (2006, p. 89, trad. nossa), de uma tese bastante simples: "a de que o real não se define por sua relação com o imaginário, mas por sua relação com o ilusório. Em outras palavras, que o imaginário é uma das formas de apreender o real, enquanto a ilusão é a maneira por excelência de negação do real". 
Tal passagem, que inicia a parte intitulada "Lo real, lo imaginário y lo ilusório” do livro Fantasmagorías, parece contraditória em relação a outra passagem do mesmo livro: "O duplo do real é o único real porque é o único que se pode perceber; o real sem duplo não é nada" (ROSSET, 2006, p. 69, trad. nossa). Contraditória porque, como vimos, a ilusão é necessariamente uma negação que ocorre por duplicação do real. Acontece, entretanto, que Rosset estabelece uma distinção fundamental entre duplos de duplicação e duplos de substituição. Os de duplicação podem até gerar uma dúvida de o que é a cópia e o que é o original, mas em nenhum momento resta a dúvida de que há um original e uma cópia (como na cena do Clube Silencio). Já os duplos de substituição são necessariamente ilusórios porquanto sua função seja a de eliminar o original fazendo-se passar por este, graças a um "efeito de alternativa" que afirma sua existência por meio da anulação de seu modelo. Logo, a ilusão é o momento objetivo de uma "ficção exteriorizada", onde não há mais distinção entre metáfora e literalidade. Quando usamos o dinheiro, por exemplo, sabemos que ele não passa de uma representação de uma possibilidade de troca, mas na efetiva ação da troca agimos como se estivéssemos lidando com "forças da natureza". Sob o capitalismo vivemos em um mundo objetivamente "encantado", por isso a ilusão independe do esclarecimento que tenhamos a seu respeito. A isso Žižek (1996, p. 316) denomina "fantasia ideológica”, uma espécie de grau zero da ideologia que funciona como um curto-circuito das fantasias:

O que as pessoas desconsideram, o que desconhecem, não é a realidade, mas a ilusão que estrutura sua realidade, sua atividade social. Eles sabem muito bem como as coisas realmente são, mas continuam a agir como se não soubessem. A ilusão, portanto, é dupla: consiste em passar por cima da ilusão que estrutura nossa relação real e efetiva com a realidade.

Disso decorre que, como afirma Rosset (2006, p. 74, trad. nossa), "O real é a única coisa do mundo a que nunca nos habituamos". Não é que o real puro seja insuportável ou inacessível, mas é que ele já é fundamentalmente estruturado por uma ficção, de tal modo que a realidade é a própria aparência de si mesma "e a única maneira apropriada de tratá-la é escrever um compêndio das aparências" (ibidem, p. 69). Qualquer critério para julgar qual realidade é mais ou menos verdadeira já nos 
coloca na ilusória posição de árbitros do que deveria ser ou não a realidade. Muito diferente é reconhecer que a realidade é, em si mesma, perspectivas sobre a realidade, aparências do real. Não há nada de mais ilusório, portanto, do que descartar todo discurso a respeito de justiça, liberdade, igualdade e bondade em nome de uma "dura realidade" de como as coisas "realmente são" - em um mesmo movimento nega-se o princípio ficcional da realidade, e essa negação é novamente negada pela conduta que segue se guiando pelo princípio negado.

Não se trata de simplesmente aceitar o real, mas de afirmá-lo, ao modo nietzschiano, em suas aparentes incompletude e insuficiência. Somente assim podemos criar um mundo, porque não existe um mundo ideal já criado à nossa espera. Qual a diferença entre o real de fato e o real percebido como real? Nenhuma: o que temos são aparências que podem servir tanto como fantasias que encobrem a realidade quanto como fantasias que se integram à realidade e a justificam - tal como faziam os deuses do Olimpo, de acordo com a reflexão de Nietzsche anteriormente citada.

Essa forma de encarar a relação entre fantasia e realidade nos faz perceber também o engodo que é a promessa tecnocientífica de nos fazer penetrar em uma realidade mais real ou, de todo modo, mais adequada a nossos desejos - que aquela acessível pelos sentidos. Nas indústrias cirúrgica e pornográfica, por exemplo, anestesias e simulação de prazer sexual já alcançam um patamar de desempenho tal que a anulação da dor e a fruição do gozo não são provocados nem por imagens/ sons virtuais, nem por estimulação dos sentidos, mas por uma intervenção neuronal direta, contornando inteiramente o nível da percepção. $\mathrm{O}$ caminho ilusório seria concluir que esse tipo de procedimento gera experiências "artificiais" mais reais do que a realidade, isto é, necessariamente mais diretas/intensas por atuarem na parte de "dentro", não aparente, do nosso corpo. Talvez isso só ocorra, entretanto, justamente porque essa "nova realidade" provoca um curto-circuito na ficção que a amparava - o próprio Hitchcock acreditava que, no futuro, um filme de terror já não teria que narrar um drama convincente, bastaria gerar as emoções adequadas a partir de um mecanismo ligado diretamente no cérebro do espectador. A suposta realidade mais real, portanto, começa a aparecer de maneira puramente negativa, como aquilo que não se estrutura como ficção. Ainda, assim, para entender essa realidade que supostamente rompe com as ficções, não há outro caminho que o da compreensão da "realidade das ficções" e da experiência de quem as vivencia. 
Em se tratando das novas formas de "estar no mundo" impulsionadas pela tecnologia, a reflexão do filósofo tchecobrasileiro Vilém Flusser (2008), em seu O Universo das Imagens Técnicas, contribui para compreendermos a prevalência das ficções em culturas pautadas na reprodução técnica de imagens "mais reais" que o real. Imagens técnicas são aquelas produzidas por aparelhos de codificação textual (baseados em fórmulas matemáticas, químicas, físicas etc.), tendo como característica principal a materialização de determinados conceitos prévios que temos em relação ao mundo, precisamente os conceitos que nortearam a construção dos aparelhos que dão forma a tais imagens. Uma fotografia, por exemplo, é produzida devido à programação da câmera - e do aparelho fotográfico de modo mais geral, se pensarmos nos laboratórios de revelação, produção dos filmes etc. - a partir de teorias da óptica e da fotoquímica. Do mesmo modo, as imagens produzidas ou reproduzidas por um software gráfico resultam de certos princípios definidos de antemão, como algoritmos baseados em determinados procedimentos fotográficos que, ao serem assim traduzidos, colocam-se à disposição de um usuário genérico, preferencialmente leigo.

Para tal usuário, todas as programações que o permitem produzir imagens através de uma câmera fotográfica ou de um computador são desconhecidas. Ou seja, o "dentro" da câmera ou do computador aparece como algo obscuro, motivo pelo qual Flusser (2011) resolve chamá-los de "caixa preta" em sua obra mais famosa, a Filosofia da caixa preta. A caixa preta ou aparelho, porém, não precisa ser necessariamente um objeto material. Podemos encarar uma fábrica de cadeiras, por exemplo, como um aparelho programado para produzir cadeiras a partir de certos inputs específicos, dentre os quais estariam a madeira, as máquinas (que eventualmente podem ser encaradas como aparelhos dentro do aparelho) e a mão-de-obra. E, de modo ainda mais abrangente, podemos pensar em todo o sistema financeiro atual como um gigantesco aparelho de geração de mais capital em relação ao qual os humanos aparecem como funcionários.

Flusser encara a proliferação dos aparelhos com extrema desconfiança, uma vez que a lógica que os impulsiona tende a limitar a realidade a um pragmatismo grosseiro - ou seja, ela estimula um empobrecimento imaginário. A lógica da eficácia que parece reger o acúmulo dos aparelhos é, enfim, uma lógica muito próxima àquela da técnica moderna identificada por Heidegger (2006) em seu Ensaio sobre a técnica. A técnica 
moderna, observa o filósofo, procura adequar o mundo às possibilidades de usos pré-estabelecidos, para os quais aquilo que aparece deve ficar à disposição. Em tal lógica, as coisas não aparecem mais para nós como um poço inesgotável de aparências, mas apenas como acúmulo de possíveis inputs para aparelhos.

Flusser, assim, não critica a realidade a partir de alguma suposta ordem superior a ela e à qual ela deveria adequar-se, mas atenta para a abertura das formas de construção imaginária intrinsecamente presentes no mundo da experiência humana. Tal abertura - esse parece ser o ponto principal da crítica - é colocada em xeque pela lógica da eficácia. Em uma realidade regida por ela, afinal, o que fica ameaçada é justamente a possibilidade de uma afirmação estética do mundo, na linha das propostas de Nietzsche e Lacan estudadas no início deste tópico.

\section{Do real da imagem}

O visível à nossa volta parece repousar em si mesmo. É como se a visão se formasse em seu âmago ou como se houvesse entre ele e nós uma familiaridade tão estreita como a do mar e da praia. No entanto, não é possível que nos fundemos nele nem que ele penetre em nós, pois então a visão sumiria no momento de formar-se, com o desaparecimento ou do vidente ou do visível. Não há, portanto, coisas idênticas a si mesmas, que, em seguida, se oferecem a quem vê, não há um vidente, primeiramente vazio, que em seguida se abre para elas, mas sim algo de que não poderíamos aproximar-nos mais a não ser apalpando-o com o olhar, coisas que não poderíamos sonhar ver inteiramente nuas, porquanto o próprio olhar as envolve e as veste com sua carne. [...] Qual a razão por que, envolvendo-os, meu olhar não os esconde e, enfim, velando-os, os desvela? (MERLEAU-PONTY, 1992, p. 128).

Da perspectiva de Merleau-Ponty, devemos sublinhar que qualquer ideia proferida acerca do mundo, qualquer teorização, não provém do mundo, mas provem de quem profere a ideia, provem de quem teoriza. Isso significa que não percebemos as coisas a partir do mundo, mas a partir do olhar. O olhar antecede, cria e recria o objeto observado. Sendo assim, a percepção não é nem uma função sensorial e fisiológica, nem um fenômeno intuitivo e transcendente (no sentido kantiano). A questão é que a forma de perceber prescreve a coisa percebida. Em outras 
palavras, cada indivíduo é como um peixe que não vê a água na qual está imerso. No caso do humano, tal água que o circunda é uma gigantesca rede de significados, redes de sentido, que estruturam seu modo de olhar. É sempre um agenciamento de imagens que está em jogo no reconhecimento do real.

Imagem nada mais é do que esta aparente mediação ao mesmo tempo real e virtual que faz o "olhar para o real" se distinguir cada vez menos do real percebido enquanto tal. A percepção do real tem sua própria imagem como uma espécie de duplo imediato, consecutivo ou mesmo simultâneo. Por exemplo: a recordação pura, como mostrava Bergson (2001), não é uma imagem que se forma após a percepção de algum objeto, mas a imagem virtual que coexiste com a percepção real do objeto - como um tipo de espelho que se apodera do objeto para que este possa ser visto. A distinção do virtual e do real corresponde à cisão mais fundamental do tempo, quando este avança, diferenciando-se segundo duas grandes vias: fazer passar o presente e conservar o passado. $\mathrm{O}$ aspecto virtual da imagem faz conservar o passado; porém, uma vez que o passado não cessa de continuar expandindo-se em cada instante seguinte, a imagem torna-se também real. É o presente que passa que define o real. Os dois aspectos da experiência, a imagem real do presente que passa e a imagem virtual do passado que se conserva, distinguem-se numa atualização cujo limite os mantém indiscerníveis, cada qual mimetizando o papel do outro.

Tal dinâmica pode ser ilustrada com o filme Sinédoque, Nova Iorque (2008) de Charlie Kaufman: na tentativa de construir uma peça de teatro que retrate o mais fielmente possível a realidade, o protagonista Caden Cotard passa anos em um galpão reconstruindo os cenários, os personagens e as experiências de sua vida. Sinédoque é uma figura de linguagem que toma a parte pelo todo. As cenas do filme são assim articuladas: os fatos não são narrados sucessivamente, mas se atropelam. Este recurso demonstra que a ordem dos fatos, os diálogos e seus respectivos significados são muito menos importantes do que a forma como foram vivenciados pelo protagonista. Além disso, essa linguagem específica ilustra o próprio presente que passa, na concepção bergsoniana, como um fluxo nunca suficiente para abarcar toda a virtualidade do passado (cujo todo é contraído a cada instante). Devemos pontuar ainda, no âmbito do enredo do filme, o fato de que Caden Cotard transforma sua própria vida numa ficção tentando com isso torná-la mais real. E ao chocar-se 
contra os limites de sua realidade particular, Cotard percebe que não existe uma única realidade possível, mas que cada ator/personagem constitui um mundo particular e, ao mesmo tempo, todos os mundos possíveis.

Há um aspecto, é preciso assinalar, que a princípio pode sugerir algum tipo de delírio romântico que nega a realidade temporal - o termo "Cotard" remete uma síndrome homônima também conhecida como síndrome do "cadáver ambulante", um delírio cujo principal sintoma é a ilusão de que se está morrendo ou de que os órgãos internos estão apodrecendo aos poucos -, uma vez que o tempo é despercebido por Caden em seu esforço de "roteirizá-lo". No entanto, se observarmos atentamente, é possível reconhecer em tal aspecto o próprio lugar da inscrição subjetiva do olhar do protagonista em sua realidade temporal. Ao reificar suas experiências, ainda que detalhadamente, e com isso desconsiderar o desenrolar "normal" do tempo, Caden parece querer capturar a descontinuidade que sua vida recebe do olho descontínuo que a observa. Em outros termos, os dois níveis temporais de Bergson, o presente que passa e o passado que se conserva, curiosamente mantem-se para Caden indiferenciados entre si, cada qual prescrevendo o outro. Sua angústia perante o tempo não é tanto a de uma queixa em relação a uma "continuidade plena" que suas experiências, apesar de constantemente atualizadas, não lhe oferecem. Ela decorre da não coincidência de um passado que para ele literalmente nunca deixou de ser presente; e, neste sentido, tal angústia, reensaiada a todo instante, não deixa de ser plenamente eficaz em reorganizar e fazer aparecer o mundo vivido. Com efeito, se Caden não percebe o tempo passar, não é por manter-se preso ao passado ou por antecipar dramaticamente a morte futura; o tempo lhe passa despercebido porque ele só se atem ao presente. E isso a partir de uma manobra particular de imaginação, a saber, pela sinédoque que produz o distanciamento necessário à experiência objetiva do real e que instaura, no mesmo movimento, a reconciliação do real com a multiplicidade imagética que ora nos aproximam ora nos distanciam dele.

Dois críticos podem ver este mesmo filme e obterem interpretações opostas, e ambos estarem completamente coerentes em seus argumentos. Tal contradição apenas atesta que aquilo que queríamos ali (o suposto "sentido do filme") nunca existiu. Isso vale para o significado de um povo, de uma classe social, de um gesto, de um objeto, de uma "sensação" - qualquer significado é feito de agenciamentos de imagens que se formam 
e desformam ao acaso, mas que só continuam em jogo na medida em que as afirmamos ou as negamos. É o que Woody Allen parece ilustrar numa das últimas cenas de Match Point (2005), quando o protagonista Chris se depara, de madrugada, com o fantasma de sua amante Nola e da vizinha, ambas assassinadas por ele. Chris diz a Nola que não foi fácil, mas que quando chegou a hora ele puxou o gatilho, e que depois foi só uma questão de esconder as provas sob o tapete e seguir em frente. A vizinha lhe pergunta se, intimamente, não se sentia nem um pouco culpado. Chris rebate citando Sófocles: "jamais ter nascido pode ser a maior dádiva de todas". Nola então o amaldiçoa dizendo que ele será descoberto e terá que pagar por seus atos. Chris concorda que isto seria o mais apropriado, pois ao menos revelaria um pequeno sinal de justiça, uma gota de esperança na aposta por "um" sentido. Mas a justiça não vem e qualquer acusação ou defesa permanece inútil frente ao fluxo dos sentidos possíveis. Somos livres para atar e desatar inúmeras relações de sentido, só que o modo como lidamos com essa falta de "um" sentido na qual as relações se ancoram ou se desfazem é o que determina essas próprias relações.

Se, com isto em mente, voltarmos a refletir sobre a problemática do Bem e da afirmação do mundo, sobre a qual discorremos anteriormente, ficará claro, uma vez mais, que a moral é impotente frente a tal fluxo das relações possíveis. A frase sofocliana citada acima, por sinal, é muito próxima daquela que Nietzsche utiliza para mostrar que os gregos conheceram e sentiram "os temores e os horrores de existir". A frase em questão é parte de uma lenda cujo tema é a captura do deus $\mathrm{Si}$ leno, companheiro de Dionísio, pelo Rei Midas. Preso, o deus foi obrigado pelo rei a responder sua pergunta: o que é o melhor para o homem? Depois de resistir durante certo tempo, Sileno finalmente diz, com um riso amarelo:

Estirpe miserável e efêmera, filhos do acaso e do tormento! Por que me obrigas a dizer-te o que seria para ti mais salutar não ouvir? O melhor de tudo é para ti inteiramente inatingível: não ter nascido, não ser, nada ser. Depois disso, porém, o melhor pra ti é logo morrer (NIETZSCHE, 2007, p. 33, destaques no original).

Essa consideração é o ponto de partida para Nietzsche refletir como os gregos, que encararam de frente o absurdo da existência, puderam construir uma cultura tão rica e jovial. A resposta oferecida pelo filósofo, como já observamos anteriormente, 
é que o fruto da potência estética desse povo - os deuses - justifica a vida humana. Ora, tal resposta pressupõe que nossa relação com o mundo, com o real, não apenas produz imagens diversas, mas antes depende dessas imagens para se constituir como experiência, ou pelo menos como experiência digna de ser vivida. Em suma, imaginação e real não são a mesma coisa, mas tampouco se opõem: "Que há uma diferença entre a imaginação e o real [...] não resta, a princípio, a menor dúvida; mas que entre ambos os âmbitos exista uma ruptura é algo, pelo contrário, muito mais duvidoso" (ROSSET, 2006, p. 106, trad. nossa).

Para Rosset, a negação do real em que consiste toda ilusão está menos relacionada a uma "imaginação excessiva" do que, antes, a uma falta de imaginação. Não há, por exemplo, incoerência alguma entre o real tal como vive diariamente Dom Quixote (de Cervantes) e o imaginário. O real do cavaleiro errante permanece inesgotável, com a diferença de aparecer sempre numa cena não habitual que configura uma espécie de espaço protegido - "entendendo por tal lugar não um lugar de escapatória do real, mas, ao contrário, um lugar onde o real está preservado, protegido daquilo que há de constitucionalmente frágil na realidade mesma" (ROSSET, op. cit., p. 112, trad. nossa). O filósofo prossegue esclarecendo que aquilo que acontece no imaginário obedece a leis tão estritas como o que acontece no real, porque no fundo se tratam das mesmas leis, com a diferença de que "O que há de impreciso no ilusório há de preciso no imaginário” (ibidem, p. 116, trad. nossa) - e também há de preciso, convém reiterar, no próprio real.

\section{Um elogio às aparências}

Ao longo deste trabalho, recorremos a pensadores como Nietzsche, Bergson, Rosset, Lacan e Žižek, dentre outros, para estudar teorias que criticam a - já abalada, mas ainda comum concepção das aparências como algo traiçoeiro e que deveria ser sempre julgado em função de qualquer coisa para além dele. Mostramos, ao longo do texto, como a relação entre o real e as imagens pode ser vista não apenas como necessária, mas - apesar dos paradoxos que a permeiam - também como passível de afirmar a vida, mais do que as concepções que tentam buscar um real inexistente para além dessa relação. Ainda com base principalmente nos mesmos autores, e utilizando alguns filmes com o intuito de ilustrar a proposta, procedemos, então, a um elogio das aparências, e mostramos como a fantasia, a beleza e 
a abertura para múltipla possibilidades interpretativas podem ser encaradas em uma visada "profundamente superficial".

Eis, por fim, a função das aparências: em vez de se deterem no aspecto "enigmático" do mundo, revelam novas formas de olhar para este mundo. Não nos parece adequado ou mesmo producente, pois, separar o real das imagens; ao contrário, o real e o imaginário estão juntos, porque este dota de sentido aquele, que é sem sentido. Entretanto, o fato de as imagens serem reais não implica que todo imaginário afirme o real: há o imaginário da ilusão (negação do real) e o imaginário do real. Em ambos os casos, porém, as aparências promovem ficções, isto é, a suposição de um "sentido oculto" que nunca se revela na medida em que não cessa de se reorganizar em novas configurações e constelações de sentido. Em todo caso, o importante a não se perder de vista é que nunca houve um sentido a ser extraído do mundo. Há apenas uma brecha que absorve nossa intenção de conhecê-lo e através da qual podemos vivenciá-lo e reinventá-lo. Lembremos também que categorias e convenções são tão ilusórias quanto necessárias: é por meio delas que o acaso nos surpreende, proporcionando-nos silêncio e espanto com uma nova aparência, uma nova experiência e uma nova realidade. É com este pacto que somos convidados a confiar nas possibilidades ainda não realizadas, a articular o que parece ser inarticulável, a contornar fronteiras invisíveis por ser esta a única maneira de atravessá-las.

\section{Referências}

BERGSON, Henry. Matéria e memória: ensaio sobre a relação do corpo com o espírito. São Paulo: Martins Fontes, 2001. A evolução criadora. São Paulo: Martins Fontes, 2006.

CRARY, Jonathan. Techniques of the Observer: On Vision and Modernity in the 19th Century. Cambridge: the MIT press, 1992.

DELEUZE, Gilles. Diferença e repetição. 2. ed. Trad. Luiz Orlandi; Roberto Machado. São Paulo: Graal, 2006.

Cinema II: a imagem-tempo. São Paulo: Brasiliense, 2009.

FLUSSER, Vilém. Filosofia da caixa preta: ensaios para uma futura filosofia da Fotografia. São Paulo: Annablume, 2011. . O universo das imagens técnicas: elogio da superficialidade. São Paulo: Annablume, 2008. 
HEIDEGGER, Martin. A questão da técnica. In: . Ensaios e conferências. 7. ed. Petrópolis: Vozes, 2006.

LACAN, Jacques. O seminário VII: a ética da psicanálise. 2. ed. Rio de Janeiro: Jorge Zahar, 2008.

MERLEAU-PONTY, Maurice. O visível e o invisível. São Paulo: Perspectiva, 1992.

NIETZSCHE, Friedrich. Crepúsculo dos Ídolos. São Paulo: Companhia das Letras, 2006.

. O nascimento da tragédia: ou helenismo e pessimismo. São Paulo: Companhia das Letras, 2007.

PESSOA, Fernando. O mistério das cousas. In: Obra Poética. Rio de Janeiro: Ed. Aguilar, 1981, p. 140-141.

ROSSET. Clément. Fantasmagorías: seguido de lo real, lo imaginario y lo ilusorio. Madrid: Abada, 2006.

SCHOPENHAUER, Arthur. Metafísica do belo. São Paulo: UNESP, 2003.

ŽIŽEK, Slavoj. Como Marx inventou o sintoma? In:

(org.) Um mapa da ideologia. Rio de Janeiro: Contraponto, 1996.

. Órgãos sem corpos: Deleuze e consequências. Trad. Manuella Assad Gómez. Rio de Janeiro: Cia. de Freud, 2008.

Recebido em: 25/o6/14

Aceito em: 13/07/14 


\section{MARCOS BECCARI}

marcosbeccari@usp.com

Doutorando no Programa de Pós-Graduação em Educação (PPGE) na Universidade de São Paulo (USP) pela linha de pesquisa "Cultura, Organização e Educação". Mestre em Design pelo Programa de Pós-Graduação em Design (PPG-Design) da Universidade Federal do Parana (UFPR), com bolsa CAPES integral. Bacharel em Design Gráfico pela mesma instituição. Co-autor do livro "Existe design?: indagações filosóficas em três vozes" (2ab, 2013).

\section{DANIEL B. PORTUGAL}

dportuga@gmail.com

Doutorando no Programa de Pós-Graduação em Comunicação e Cultura (PPGCOM) na Universidade Federal do Rio de Janeiro (UFRJ), com bolsa CAPES parcial e bolsa sanduíche do CNPQ. Mestre em Comunicação e Práticas de Consumo (PPGCOM) pela Escola Superior de Propaganda e Marketing (ESPM-SP), com bolsa Fundação de Apoio a Pesquisa do Estado de São Paulo (FAPESP) integral. Bacharel em Design Gráfico pela UFRJ. Co-autor do livro "Existe design?: indagações filosóficas em três vozes" (2ab, 2013). 